Methods in Cell Science

January 2004; 25(3-4) : 177 - 184

http://dx.doi.org/10.1007/s11022-004-8227-4

(c) 2004 Springer Science+Business Media
Archimer, archive institutionnelle de l'Ifremer http://www.ifremer.fr/docelec/

\title{
Isolation and primary culture of gill and digestive gland cells from the common mussel Mytilus edulis
}

\author{
Jérôme Faucet ${ }^{1,3^{*}}$, Manuelle Maurice ${ }^{1}$, Béatrice Gagnaire ${ }^{2}$, \\ Tristan Renault ${ }^{2}$ and Thierry Burgeot ${ }^{2}$
}

\author{
${ }^{1}$ IFREMER, Direction Environement Littoral, Département Polluants chimiques, Laboratoire drsquoEcotoxicologie, \\ Nantes, France \\ ${ }^{2}$ IFREMER, Laboratoire de Génétique et Pathologie, La Tremblade, France \\ ${ }^{3}$ FREMER, Centre de Nantes, Direction Environement Littoral, Département Polluants chimiques, Laboratoire \\ drsquoEcotoxicologie, Rue de Irsquolle drsquoYeu, B.P. 21105, 44311, Nantes Cedex 03, France \\ *: Corresponding author : Jérôme Faucet Email: Thierry.Burgeot@ifremer.fr Phone: 33(2) 40374051 \\ Fax: 33(2) 40374075
}

\begin{abstract}
As the marine mussel Mytilus edulis is commonly used as a sentinel species, it would be useful to develop a primary culture of the target organs most often in contact with the marine environment. This study reports an improved method for dissociating the digestive gland and gills of $M$. edulis and considers the effect of mussel storage on cell viability and functionality before culture initiation. Viability and enzymatic activities such as those of esterase and peroxidase were monitored by flow cytometry, a sensitive, objective technique allowing large volumes of cells to be counted within a short time. A primary culture of digestive gland showed more than $75 \%$ viability after $72 \mathrm{~h}$. Mussels were maintained in an aquarium containing clean, oxygenated seawater at $12{ }^{\circ} \mathrm{C}$ for two days before culture initiation, and dissociation was performed mechanically and chemically with Ca-Mg-free saline to obtain digestive gland cells. Application of nonspecific esterase activity, using fluorescein diacetate (FDA test) coupled with flow cytometry, characterised the functionality of digestive gland and gill cells in culture.
\end{abstract}

Keywords: Cell culture - Digestive gland - Flow cytometry - Gill - Mytilus edulis 


\section{Introduction}

Molluscs are regarded as important indicator organisms for environmental quality assessment. In this respect, bivalves are especially appropriate because they are generally sessile, live in close contact with benthic substrates and sediment, and filter vast quantities of water [18]. Mollusc models have been highly useful in toxicology and ecotoxicology, but mollusc cell cultures are needed to study the organs most often in contact with the marine environment, i.e. mantle, gills and digestive gland [14]. Bivalve digestive gland is particularly suitable for cultures [14], as it is the main site of digestion/assimilation [13] and possesses the same broad phase I and II pathways of xenobiotic metabolism as those in vertebrates [15]. Robledo and Cajaraville [22] isolated and characterised digestive gland cells from Mytilus galloprovincialis by explant cultures and mechanical plus enzymatic digestion techniques. A primary culture of mixed-cell populations isolated by chemical digestion from the digestive gland of the marine mussel $M$. edulis, a sentinel species used in environmental monitoring, has also been developed for potential applications in toxicological studies [3]. Mollusc gills, whose filter function makes them the initial target for toxicants in the aquatic environment, have also been studied for the development of primary cell cultures [7]. As mucus sticks to gill tissue and harbours many potential contaminant micro-organisms, a dissociation protocol was required [7]. Mothersill et al. [17] have emphasised the importance of hygiene and the need to apply an appropriate disinfectant technique to the whole animal before dissection and tissue dissociation in order to reduce contamination prior to initiation of cell cultures. Rapidity in obtaining cells is also an important parameter for the development of primary cell cultures [17]. However, the functionality of most primary cultures for marine invertebrates is uncertain [6]. Many 
enzyme activities disappear in vitro and are no longer available as markers of tissue specificity [10]. The use of fluorogenic probes in flow cytometry (see Shapiro [24]) allows measurement of viability and enzymatic activities. These measurements combine the advantages of biochemical and histological enzyme determinations, and enzyme activity can be precisely quantified. Automated differential white mammalian cell counts can be performed by flow cytometry [16]. Esterase [16], phosphatase [16] and aminopeptidase [12] activities of human blood leucocytes have been determined, as well as algal esterase and peroxidase activities [1, 4, 21]. Among aquatic invertebrates, studies have been mainly performed on haemocytes. Phagocytic response and viability have been measured following in vitro or in vivo exposure to heavy metals [5, 8, 23] or contaminated marine sediments [9]. Other enzymatic (e.g. peroxidase) activities have been determined in marine invertebrates by flow cytometry [27]. Gagnaire et al. [11] studied the effects of atrazine on the Pacific oyster Crassostrea gigas by measuring esterase activity in haemocytes.

The present study reports an improved method for dissociating the digestive gland and gills of $M$. edulis, a species widely used for in vitro models [25]. Before initiation of cell culture, animals were maintained for $48 \mathrm{~h}$ in seawater without feeding to reduce the risk of contamination. Flow cytometry was used to compare the viability and functionality (esterase and peroxidase activities) of cells obtained after and in the absence of a 48-h storage period. Two dissociation methods were also compared: a slow chemical digestion technique using Ca-Mg-free saline (CMFS) buffer and a more rapid mechanical plus slow chemical (CMFS) digestion technique. 


\section{Materials}

A. Animals and chemicals:

1. Specimens of $M$. edulis (4-5 cm length) were collected from an unpolluted site at Le Vivier sur Mer in Mont Saint Michel Bay (Ile et Vilaine, France).

2. Underground seawater sampled at a depth of $110 \mathrm{~m}\left(12^{\circ} \mathrm{C}\right)$ was obtained off the coast of Ronce les Bains (Charente Maritime, France).

3. Sodium chloride, No. S-3014. ${ }^{1}$

4. Potassium chloride No. P-4504. ${ }^{1}$

5. Ethylenediamine-tetraacetic acid (EDTA), No.E-5134. ${ }^{1}$

6. Calcium chloride dihydrate, No. 22,350-6. ${ }^{1}$

7. Magnesium sulphate, No. M-7774. ${ }^{1}$

8. Magnesium chloride 6-hydrate, No. $131396 .^{2}$

9. Hepes, No. H-3784. ${ }^{1}$

10. L15 (Leibovitz) medium, No.L-4386. ${ }^{1}$

11. Tylosin solution, No. T-3397. ${ }^{1}$

12. Penicillin G, No. P-3032. ${ }^{1}$

13. Streptomycin sulphate, No. S-9137. ${ }^{1}$

14. Gentamycin sulphate, No. G-1264. ${ }^{1}$

15. Fœtal bovine serum, No. 10500-056. ${ }^{3}$

16. Eosin Y, No. E-4382. ${ }^{1}$

17. Propidium iodide, $\mathrm{P}-3566^{6}$

18. Cell Probe fluorescein diacetate (FDA) esterase, PN $7547081^{7}$ 
20. Cell Probe dichlorofluorescein diacetate (DCFH-DA), phorbol myristate acetate (PMA) Owidative Burst, PN 7547078

B. Glass- and plasticware:

1. Sterile Petri dishes (35 x $10 \mathrm{~mm}$ ), No. $19001.01^{4}$

2. Sterile centrifuge tubes ( $15 \mathrm{ml})$, No. $19259.01^{4}$

3. Sterile centrifuge tubes ( $225 \mathrm{ml})$, No. $19333.01^{4}$

4. Twenty -four-well culture plates, No. $79039.01^{4}$

5. Bluter nylon $(37 \mu \mathrm{m})$, No. $87403.01^{4}$

6. Bluter nylon $(100 \mu \mathrm{m})$, No. $87410.01^{4}$

7. Cell-counting chamber, Bright-line haemacytometer, No. Z35,9629 ${ }^{1}$

8. Cell-counting chamber, Neubauer improved, No.00520.01 ${ }^{4}$

9. Filter unit $(0.2 \mu \mathrm{m})$, No. $94832.01^{4}$

10. Microscopy scissors, No. $63036.01^{4}$

11. Scalpel blades, No. $24460.01^{4}$

12. Pincers, No. $81256.01^{4}$

13. Teflon potter, No. $64220.01^{4}$

14. Three inox strainers (2.38 mm, mesh 8, 100 x $40 \mathrm{~mm})$, No. 5820.01

15. Plastic tubes, No $2523749^{7}$

C. Equipment:

1. NP $72 \mathrm{I}^{8}$ cell culture hood

2. CL J6 $\mathrm{ME}^{7}$ centrifuge 
3. CK $2^{9}$ inverted microscope

4. CB $161^{10}$ magnetic stirrer

5. Masterflex L/S ${ }^{5}$ pump system

6. EPICS XL4 ${ }^{7}$ flow cytometer

\section{Procedures}

A. Preparation of M. edulis:

1. Mussels (three pools of 25 animals) were cleaned of epibiotic growth, and the shell surface was decontaminated with $75 \%$ ethanol and dried as recommended by Mothersill et al. [17].

2. The first pool (pool A) was placed in an aquarium containing oxygenated seawater (5 animals/l) at $12^{\circ} \mathrm{C}$ supplemented with penicillin and streptomycin sulphate overnight (final concentration: 100 units/l and $100 \mathrm{mg} / \mathrm{l}$, respectively) directly after sampling.

3. The other two pools (pools B and C) were maintained in an aquarium for two days in clean oxygenated seawater (5 animals/l) at $12^{\circ} \mathrm{C}$, which was changed daily. After two days, penicillin and streptomycin sulphate were added overnight.

B. Dissection and washing:

All procedures were carried out under sterile conditions within a laminar flow hood in a thermoregulated room $\left(18^{\circ} \mathrm{C} \pm 1^{\circ} \mathrm{C}\right)$.

1. After overnight storage in seawater supplemented with antibiotics (pool A) or two days of storage in seawater and one night with antibiotics (pools B and C), 
mussels were opened with a scalpel and digestive glands and gills were collected with sterile scissors and pincers.

2. Tissues were trimmed to remove all traces of mantle and kidney. The crystalline in digestive glands was also removed.

3. Selected tissues were placed in a tared sterile Petri dish on ice and weighed.

4. Digestive glands and gills were transferred into flasks.

5. Tissues were washed twice in CMFS buffer (10 ml/gland or pair of gills) containing $1 \%$ gentamycin sulphate (final concentration: $0.1 \mathrm{mg} / \mathrm{ml}$ ), with gentle stirring for $5 \mathrm{~min}$.

6. Washing solutions were filtered on a sterile inox strainer, and tissues were recovered.

\section{Dissociation :}

Protocol 1: soft dissociation: pools A and B:

Digestive gland dissociation

Dissociation of digestive glands was performed according to Birmelin et al. [2].

1. Digestive glands were placed in a beaker containing $50 \mathrm{ml} \mathrm{CMFS} \mathrm{buffer}$ supplemented with gentamycin (1\%) and minced into small pieces (2 mm) using three sterile scissors.

2. The glands were transferred into a flask containing $250 \mathrm{ml}$ CMFS buffer including gentamycin (1\%) and stirred gently for $2 \mathrm{~h}$ with a magnetic stirrer (100 rpm). 
3. Aliquots of the cell suspension were removed every 30 min and replaced with fresh CMFS buffer/gentamycin.

4. Cell suspensions were filtered on inox strainers through $100 \mu \mathrm{m}$ and $37 \mu \mathrm{m}$ sterile Bluter nylon.

5. Filtrate was centrifuged at $100 \mathrm{~g}$ for $5 \mathrm{~min}$ to spin down mainly larger cells and then again at $180 \mathrm{~g}$ for 5 min to obtain smaller cells [2].

6. Pelleted cells from both spins were resuspended in culture medium (L15 modified medium) and centrifuged again at $100 \mathrm{~g}$ and $180 \mathrm{~g}$ for $5 \mathrm{~min}$ to remove CMFS buffer.

\section{Gill dissociation}

Gill dissociation was performed according to Wilson et al. [28].

1. Gills were placed in a beaker containing 50 ml CMFS buffer supplemented with gentamycin (1\%) and then excised and chopped using three sterile scissors.

2. Chopped gills were transferred into a flask containing $250 \mathrm{ml}$ CMFS buffer including gentamycin (1\%) and stirred gently for $1 \mathrm{~h}$ with a magnetic stirrer (100 rpm).

3. Aliquots of the cell suspension were removed and filtered on inox strainers through $100 \mu \mathrm{m}$ and $37 \mu \mathrm{m}$ sterile Bluter nylon.

4. Filtrate was centrifuged at $200 \mathrm{~g}$ for $10 \mathrm{~min}$ to spin down the cells.

5. Pelleted cells were resuspended in culture medium (L15 modified medium) and centrifuged again at $200 \mathrm{~g}$ for $10 \mathrm{~min}$ to remove CMFS buffer. 
Protocol 2: mechanical dissociation: pool C:

1. Digestive glands or gills were placed in a Teflon potter with CMFS buffer containing gentamycin (1\%) and minced to obtain a cell suspension.

2. The cell suspension was transferred into a flask and completed to $250 \mathrm{ml}$ with CMFS buffer containing gentamycin (1\%).

3. The same procedure as for protocol 1 was then performed to filter and centrifuge the cell suspension.

D. Primary cell cultures

1. Pelleted cells (from digestive gland or gill) were resuspended in culture medium (L15 modified medium), and cell density was measured using a cell-counting chamber (Neubauer improved).

2. Culture medium was added to obtain a density of $410^{6}$ cells per ml.

3. The viability of isolated cells was measured by dye exclusion using the red dye eosin $\mathrm{Y}$.

4. One millilitre of cell suspension (4 $10^{6}$ cells) was distributed per culture plate well, and the plate was placed in a cell culture incubator at $18^{\circ} \mathrm{C}$.

E. Flow cytometry measurements

Cells were analysed using flow cytometry (EPICS XL 4, Beckman Coulter), with 3,000 events counted for each sample. Results are expressed in the form of cell cytograms indicating the size (FSC value), complexity (SSC value) and fluorescence channel(s) corresponding to the marker used. 
1.Two hundred microlitres of the cell suspension were distributed in a cytometer tube for each activity monitored.

2. Twenty microlitres of the corresponding commercial kits (FDA•Esterase, A Aminopeptidase $\mathrm{M}$ and $\mathrm{DFCH}, \mathrm{PMA} \bullet$ Oxidative Burst) were incubated in the dark at ambient temperature for 15 min for esterases and peroxidases and 30 min for aminopeptidases.

3. Incubation was performed in the dark for $30 \mathrm{~min}$ at $4{ }^{\circ} \mathrm{C}$ with $10 \mu \mathrm{L}$ of propidium iodide.

4. The sample was placed in the flow cytometer.

F. Culture media, solutions and chemicals:

1. Culture medium: $1100 \mathrm{mOsm}, \mathrm{pH} 7.3$ :

$\begin{array}{lc}\mathrm{L} 15 \text { (Leibovitz) medium } & 15.08 \mathrm{~g} / \mathrm{l} \\ \mathrm{NaCl} & 20.2 \mathrm{~g} / \mathrm{l} \\ \mathrm{KCl} & 0.54 \mathrm{~g} / \mathrm{l} \\ \mathrm{CaCl}_{2} & 0.6 \mathrm{~g} / \mathrm{l} \\ \mathrm{MgSO}_{4} & 1 \mathrm{~g} / \mathrm{l} \\ \mathrm{MgCl}_{2} & 3.9 \mathrm{~g} / \mathrm{l}\end{array}$

Distilled water was added and $\mathrm{pH}$ was adjusted to 7.3. Modified L15-medium was sterilised by filtration through a $0.22 \mu \mathrm{m}$ filter. Medium was supplemented with $10 \%$ fœtal bovine serum (v/v), tylosin solution $(1 \mathrm{ml} / \mathrm{l})$ and $1 \%$ gentamycin sulphate $(1 \mathrm{mg} / \mathrm{ml})$ just before use.

2. CMFS buffer: 1100 mOsm, pH 7.3 [19]: 
HEPES

$\mathrm{NaCl}$

$\mathrm{KCl}$

EDTA
$5.2 \mathrm{~g} / \mathrm{l}$

$29.22 \mathrm{~g} / \mathrm{l}$

$0.93 \mathrm{~g} / \mathrm{l}$

$1.86 \mathrm{~g} / \mathrm{l}$

Distilled water was added and $\mathrm{pH}$ was adjusted to 7.3. Sterilisation was performed by filtration through a $0.22 \mu \mathrm{m}$ filter. CMFS buffer was supplemented with $1 \%$ gentamycin sulphate $(1 \mathrm{mg} / \mathrm{ml})$ just before use.

3. Gentamycin stock solution:

Gentamycin sulphate $10 \mathrm{mg} / \mathrm{ml}$

CMFS buffer or modified L15-medium was added. Sterilisation was performed by passage through a $0.22 \mu \mathrm{m}$ filter. Aliquots were stored at $-20^{\circ} \mathrm{C}$.

\section{Results and discussion}

The experiments performed were intended to improve mussel storage and tissue dissociation from gills and digestive glands and to determine which tissue was preferable for use in primary cell cultures. The results are based on an adapted version of the primary culture method developed for M. edulis by Wilson et al [28] and Birmelin et al. [2]. The tissue dissociation procedure was improved in order to obtain a good dissociation yield and quite good cell preservation. The techniques of Wilson et al. [28] and Birmelin et al. [2]. are based on associating the dissociation buffer (CMFS) with gentle stirring. As this method requires 2-3 h for digestive glands and $1 \mathrm{~h}$ for gills, a more rapid and convenient dissociation method is needed. In our study, the efficiency of mechanical treatment was checked by using a Teflon potter (protocol 2: pool C), and the dissociation yield and 
viability obtained were compared with the classical dissociation method (protocol 1: pools A and B) (Table 1). Animals were also maintained for $48 \mathrm{~h}$ in seawater without feeding (pools B and C) to reduce the risk of contamination before initiation of cell cultures.

A. Effects on of storage and the dissociation method on viability and dissociation yield Effects of the dissociation method

Dissociation yield (Table 1) with the slow dissociation method (11.8 $10^{6}$ cells/g w.w from gills and $63.110^{6}$ cells/g w.w from digestive glands) was significantly better than that with the mechanical method $\left(3.210^{6}\right.$ cells/g w.w from gills and $5.910^{6}$ cells/g w.w from digestive glands).

Table 1. Dissociation yield and percentage of cell viability obtained with two dissociation procedures. Viability was measured by eosin $\mathrm{Y}$ exclusion and dissociation yield is expressed in millions of cells per gram of tissue (wet weight). $\mathrm{P}=$ probability of the MannWhitney test, $*=$ statistically significant.

\begin{tabular}{|c|c|c|c|c|}
\hline Dissociation mode & & $\begin{array}{l}\text { Pools A and B } \\
\text { Protocol 1: Slow }\end{array}$ & \multicolumn{2}{|c|}{$\begin{array}{c}\text { Pool C } \\
\text { Protocol 2: Mechanical }\end{array}$} \\
\hline Dissociation yield: & Gill cells & $\begin{array}{c}11.8 \pm 8.63 \\
N=3\end{array}$ & $3.2 \pm 0.10 \mathrm{~N}=3$ & $\mathrm{p}=0.05^{*}$ \\
\hline $10^{6}$ cells/g w.w & Dig. gland cells & $\begin{array}{c}63.1 \pm 26.43 \\
\mathrm{~N}=3\end{array}$ & $5.9 \pm 1.65 \mathrm{~N}=3$ & $\mathrm{p}=0.05^{*}$ \\
\hline$\%$ viability by dye & Gill cells & $\begin{array}{c}76.1 \pm 12.23 \\
N=3\end{array}$ & $\begin{array}{c}83.6 \pm 0.64 \\
N=3\end{array}$ & $\mathrm{p}>0.05$ \\
\hline exclusion & Dig. gland cells & $\begin{array}{c}90.7 \pm 1.18 \\
\mathrm{~N}=3\end{array}$ & $\begin{array}{c}94.5 \pm 2.04 \\
N=3\end{array}$ & $\mathrm{p}>0.05$ \\
\hline
\end{tabular}


Cell viability was assessed by standard methods using vital dye (Table 1) and eosin $\mathrm{Y}$, as well as by flow cytometry measurements (Table 2). Although viability tests by flow cytometry are statistically more rigorous than standard methods using vital dye, this assay is rarely applied to aquatic invertebrates [17]. Viability as measured by vital dye did not differ significantly for the two methods, i.e. $75 \%$ for gill cells and $90 \%$ for digestive gland cells (Table 1). Cell viability measured by flow cytometry (Table 2) and obtained with mechanical dissociation (pool C) was significantly greater than that reported for the slow dissociation method (pools A and B) (Table 2 and Fig. 1). With the mechanical method, the percentage of viability just before initiation of cell culture was $81.3 \pm 2.31 \%$ for gill cells and $94.5 \pm 0.75 \%$ for digestive gland cells. These results show the greater precision of flow cytometry measurements as compared to standard methods using vital dye. 
Table 2. Percentages of viability, esterase and peroxidase-positive cells obtained with two storage procedures and dissociation modes. $\mathrm{P}=$ probability of the Mann-Whitney test, $*=$ statistically significant, $* *=$ highly statistically significant, $(\mathrm{a})=$ comparison between pool A and B, (b) = comparison between pool B and C.

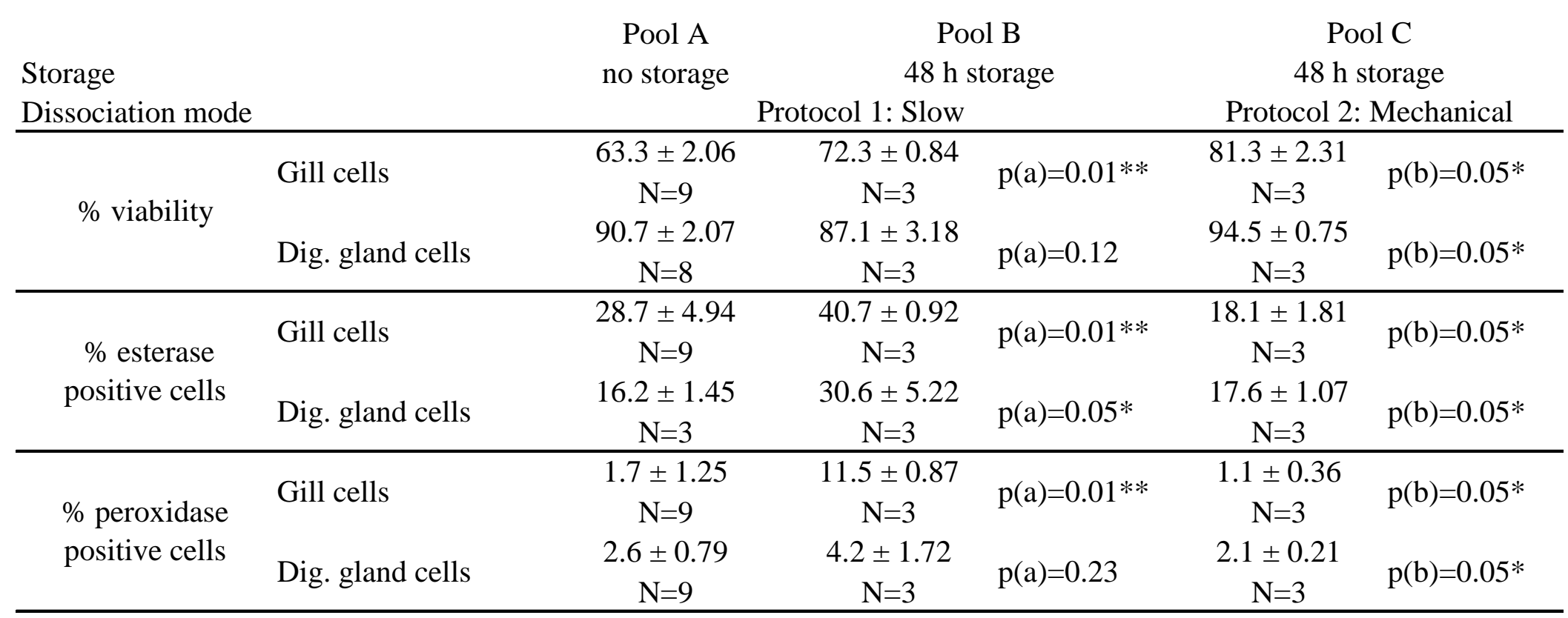


Figure 1: Mean viability of digestive gland cells and gill cells as measured by flow cytometry before initiation of cell culture.

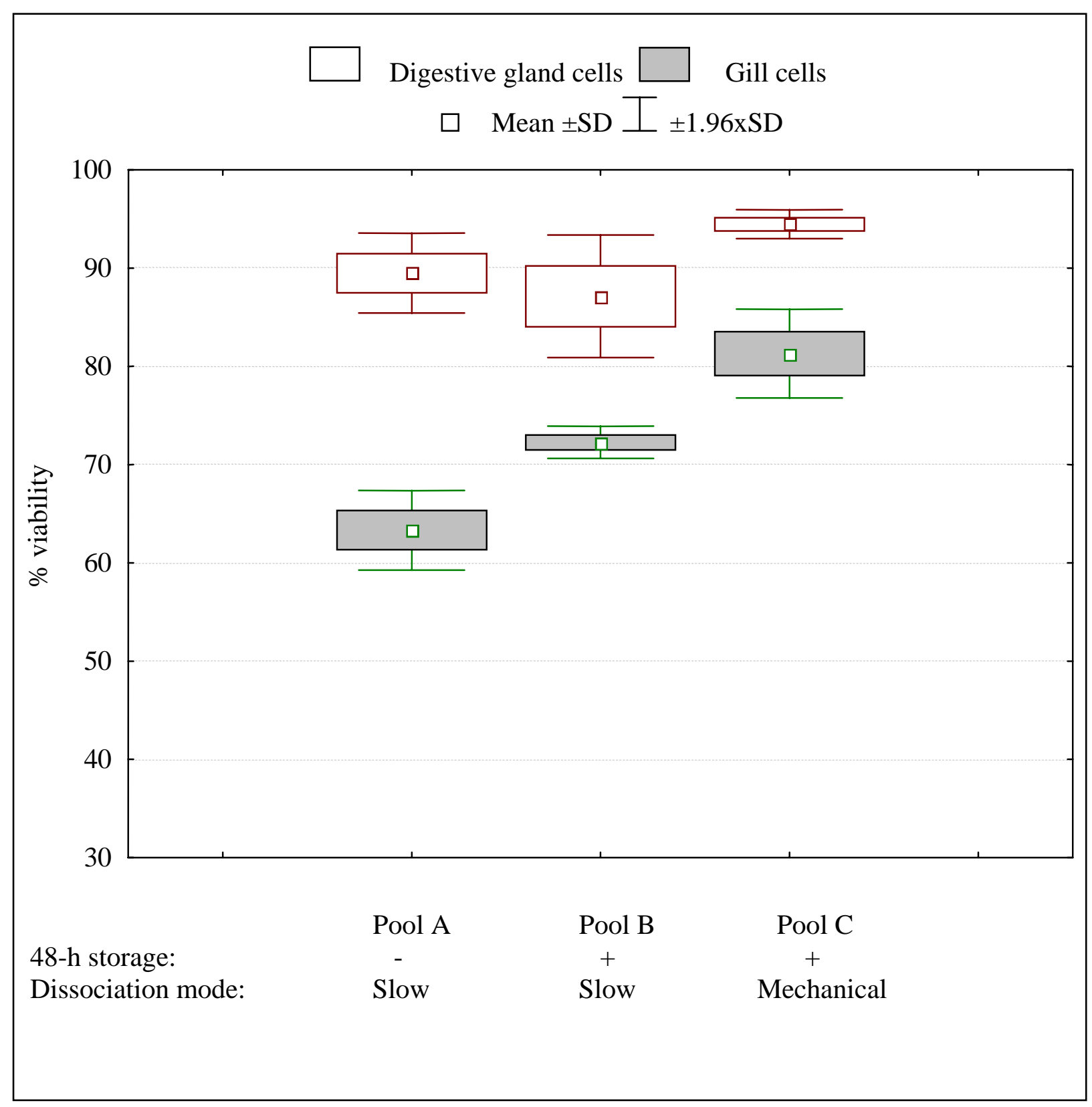

\section{Storage effects}

Viability as measured by flow cytometry showed the highly significant effect of 48-h storage for gill cells (Table 2 and Fig. 1). The percentage of viability increased from $63.3 \pm 2.06 \%$ (pool A: without storage) to $72.3 \pm 0.84 \%$ and $81.3 \pm 2.31 \%$ (pools B and C with storage). Storage may allow gills to recover after the stress caused by sampling and emersion. 
A similar effect was not found for digestive gland cells (Table 2), but storage in an aquarium containing oxygenated seawater may reduce the presence of pathogenic micro-organisms.

\section{Effects after16 $\mathrm{h}$ in culture}

After $16 \mathrm{~h}$ in culture at $18^{\circ} \mathrm{C}$, there was no significant difference between the results obtained with the two dissociation procedures. The percentage of viability decreased to $43.7 \pm 1.89 \%$ and $49.4 \pm 5.50 \%$ for gill cells, but remained at $84.6 \pm 2.00 \%$ and $85.9 \pm 1.49 \%$ for digestive gland cells (Table 3, Fig. 2).

Table 3. Percentages of viability and esterase-positive cells obtained with two storage and dissociation procedures after $16 \mathrm{~h}$ at $18^{\circ} \mathrm{C}$ in a cell culture incubator. $\mathrm{P}=$ probability of the Mann-Whitney test, * = statistically significant.

$$
\text { Pool A Pool C }
$$

Storage

no storage

48 h storage

Dissociation mode Protocol 1: Slow Protocol 2: Mechanical

\begin{tabular}{|c|c|c|c|c|}
\hline & & \multirow[b]{2}{*}{$\begin{array}{c}43.7 \pm 1.89 \\
\mathrm{~N}=9\end{array}$} & \\
\hline \multirow{2}{*}{$\%$ viability } & & & $\begin{array}{c}49.4 \pm 5.50 \\
N=3\end{array}$ & $\mathrm{p}=0.16$ \\
\hline & Dig. gland cells & $\begin{array}{c}84.6 \pm 2.00 \\
N=9\end{array}$ & $\begin{array}{c}85.9 \pm 1.49 \\
\mathrm{~N}=3\end{array}$ & $\mathrm{p}=0.27$ \\
\hline \multirow{2}{*}{$\begin{array}{c}\% \text { esterase } \\
\text { positive cells }\end{array}$} & Gill cells & $\begin{array}{c}11.8 \pm 1.72 \\
\mathrm{~N}=3\end{array}$ & $\begin{array}{c}19.7 \pm 2.60 \\
N=3\end{array}$ & $\mathrm{p}=0.05^{*}$ \\
\hline & Dig. gland cells & $\begin{array}{c}10.6 \pm 3.26 \\
N=9\end{array}$ & $\begin{array}{c}15.3 \pm 4.59 \\
N=3\end{array}$ & $\mathrm{p}=0.16$ \\
\hline
\end{tabular}


Figure 2: Mean viability of digestive gland cells and gill cells as measured by flow cytometry $16 \mathrm{~h}$ after initiation of cell culture.

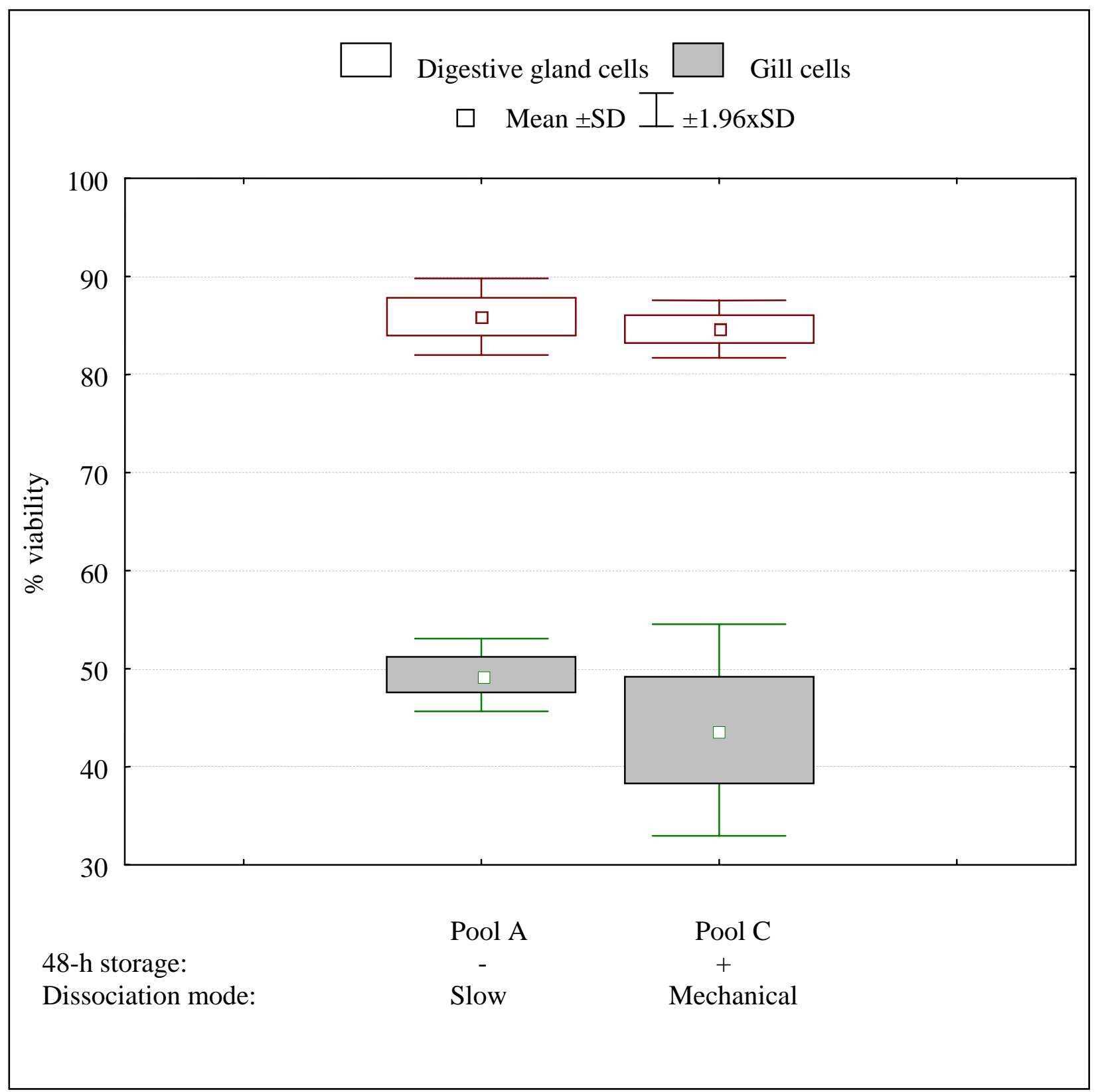

B. Effects of storage and the dissociation method on the functional condition of cells Effects on esterase activity 
The percentage of cells with esterase activity showed a significant decrease between slow dissociation (pool B, $40.7 \pm 0.92 \%$ for gill cells and $30.6 \pm 5.22 \%$ for digestive gland cells) and mechanical dissociation (pool C, $18.1 \pm 1.81 \%$ for gill cells and $17.6 \pm 1.07 \%$ for digestive gland cells) (Table 2). The values observed for the different pools are consistent with those previously reported [11] for C. gigas haemocytes after 4 h of in vitro incubation (35\%). Mechanical dissociation, though faster than classical dissociation, might decrease some enzymatic activities (e.g. that of esterase).

However, the effect of storage mode was also significant concerning the percentage of cells showing esterase activity (Table 2). This rate was higher for cells that underwent 48-h storage (pool B, $40.7 \pm 0.92 \%$ for gill cells and $30.6 \pm 5.22 \%$ for digestive gland cells) than those without storage (pool A, $28.7 \pm 4.94 \%$ for gill cells and $16.2 \pm 1.45 \%$ for digestive gland cells). After $16 \mathrm{~h}$ of culture, esterase activity was still apparent for both cell types, and this activity was significantly greater for gill cells with mechanical dissociation and storage (19.7 $\pm 2.6 \%$ vs $11.8 \pm 1.72 \%)$ (Table 3 ). Storage might have a beneficial effect on cells by favouring the recovery of functional tissue conditions after sampling stress.

\section{Effects on peroxidase activity}

The percentage of peroxidase-positive cells was very low (5\% for digestive gland cells and $2 \%$ for gill cells) (Table 2), as compared to peroxidase activity measured on C. gigas haemocytes [11] after $4 \mathrm{~h}$ of in vitro incubation (12\%). For pool B, gill cell values reached $11.5 \pm 0.87 \%$ (Table 2). Peroxidase activity is known to be related to phagocytic activity [26, 20, 27], which is especially present in haemocytes. The relatively high percentage obtained with pool B gill cells might have been due to the presence of haemocytes with phagocytic activity. 
This study considers the effects of storage and the dissociation method used on the viability and cellular functionality of a primary cell culture of mussels. These effects were especially apparent immediately after dissociation, particularly with gill cells, i.e. frail cells difficult to decontaminate, but no difference was observed after 16 h. Nonetheless, mechanical dissociation is faster and easier to perform than the classical method. Moreover, digestive gland cells are more appropriate than gill cells for primary mussel cell cultures, showing more than $80 \%$ viability after $16 \mathrm{~h}$ and more than $75 \%$ after $72 \mathrm{~h}$ (as measured using the vital dye, eosin Y).

Measurement of esterase activity allowed us to monitor the functional condition of cells in primary cultures. As a result, mussels were maintained for two days in an aquarium in clean, oxygenated seawater (5 animals/l) at $12^{\circ} \mathrm{C}$ and mechanical dissociation was used to obtain digestive gland cells. This method allows the development of primary cell cultures of the sentinel species M. edulis for applications in ecotoxicology.

\section{Notes on suppliers}

1. Sigma Chemical Company, Saint Quentin Fallavier, France

2. Panreac: Montplet \& Etteban SA, Barcelona, Spain

3. Life Technologies, Cergy Pontoise, France

4. Merck-Eurolab Polylabo, Strasbourg, France

5. Fisher BioBlock, Illkirch, France

6. Interchim Molecular Probes, Montluçon, France

7. Beckman Coulter, Roissy, France

8. Gelaire, 2009 Opera (MI) Via Lombro, 23125 Italy

9. Olympus, France

10. Bibby Sterilin Ltd, UK 


\section{Acknowledgement}

The authors are grateful to the Seine Aval Program for financial support. 


\section{References}

1. Arsenault G, Cvetkovic AD, Popovic R. Toxic effects of copper on Selenastrum capricornutum measured by flow cytometry-based method. Water Poll Res J Canada 1993; 28(4), 757-765.

2. Birmelin C, Mitchelmore CL, Goldfarb PS, Livingstone DR. Characterisation of biotransformation enzyme activities and DNA integrity in isolated cells of the digestive gland of the common mussel, Mytilus edulis L. Comparative Biochemistry and Physiology - Part A 1998; 120: 51-56.

3. Birmelin C, Pipe RK, Goldfarb PS, Livingstone DR. Primary cell-culture of digestive gland of marine mussel Mytilus edulis: a time-course study of antioxidant- and biotransformationenzyme activity and ultrastructural changes. Mar Biol 1999;135: 65-75.

4. Blaise C, Menard L. A micro-algal solid phase test to assess the toxic potential of freshwater sediments. Water Qual Res J Canada 1998; 33(1): 13-151.

5. Brousseau P, Pellerin J, Morin Y, Cyr D, Blakley B, Boermans H, Fournier M. Flow cytometry as a tool to monitor the disturbance of phagocytosis in the clam Mya arenaria hemocytes following in vitro exposure to heavy metals. Toxicology 2000; 142: 145-156.

6. Domart-Coulon I, Doumenc D, Auzoux-Bordenave S, Le Fichant Y. Identification of media supplements that improve the viability of primary cell cultures of Crassostrea gigas oysters. Cytotechnology 1994; 16: 109-120.

7. Domart-Coulon I, Auzoux-Bordenave S, Doumenc D, Khalanski M. Cytotoxicity assessment of antifouling compounds and by-products in marine bivalve cell cultures. Toxicology in Vitro 2000; 14: 245-251.

8. Fournier M, Pellerin J, Clermont Y, Morin Y, Brousseau P. Effects of in vivo exposure of Mya arenaria to organic and inorganic mercury on phagocytic activity of hemocytes. Toxicology 2001; 161: 201-211. 
9. Fournier M, Pellerin J, Lebeuf M, Brousseau P, Morin Y, Cyr, D. Effects of exposure of Mya arenaria and Mactromeris polynyma to contaminated marine sediments on phagocytic activity of hemocytes. Aquat Toxicol 2002; 59: 83-92.

10. Freshney RI. Cell culture of animal cells. A manual of basic techniques. $3^{\text {rd }}$ Wiley-Liss, New York, 1994.

11. Gagnaire B, Renault T, Bouilly K, Lapegue S, Thomas-Guyon H. Study of atrazine effects on Pacific oyster, Crassostrea gigas, haemocytes. Cur. Pharm. Design 2003; 9: 193-199.

12. Ganesh S, Klingel S, Kahle H, Valet G. Flow cytometric determination of aminopeptidase activities in viable cells using fluorogenic rhodamine 110 substrates. Cytometry 1995; 20: 334-340.

13. Henry M. La glande digestive de la palourde méditerranéenne Ruditapes decussatus L. Recherches ultrastructurales, cytochimiques, écophysiologiques et écotoxicologiques. Vie Mar 1987; 1: 1-407.

14. Le Pennec G, Le Pennec M. Evaluation of the toxicity of chemical compounds using digestive acini of the bivalve mollusc Pecten maximus L. maintained alive in vitro. Aquat. Toxicol 2001; 53: 1-7.

15. Livingstone DR. Recent developments in marine invertebrate organic xenobiotic metabolism. Toxicol Ecotoxicol News 1994; 1:88-94.

16. Malin-Berdel J, Valet G. Flow cytometric determination of esterase and phosphatase activities and kinetics in hematopoietic cells with fluorogenic substrates. Cytometry 1980; 1: 222-228.

17. Mothersill C, Mulford AL, Austin B. Basic methods and media. In : Mothersill C, Austin, eds. Aquatic invertebrate cell culture. Chichester: Springer Praxis-Publishers, 2000: 9-14.

18. Mulcahy MF. Culture of molluscan cells. In: Mothersill C, Austin, eds. Aquatic invertebrate cell culture. Chichester: Springer Praxis-Publishers, 2000: 165-176. 
19. Peek K, Gabbott PA. Adipogranular cells from the mantle tissue of Mytilus edulis. Isolation, purification and biochemical characteristics of dispersed cells. J Exp Mar Biol Ecol 1989; 126: 203-216.

20. PIPE RK. Generation of reactive oxygen metabolites by the haemocytes of the mussel Mytilus edulis. Develop Comp Immuno 1992; 16: 111-122.

21. Regel R, Ferris JM, Ganf GG, Brookes JD. Algal esterase activity as a biomeasure of environmental degradation in a freshwater creek. Aquat Toxicol 2002; 59: 209-223.

22. Robledo Y, Cajaraville MP. Isolation and morphofunctional characterisation of mussel digestive gland cells in vitro. Eur Jour Cell Biol 1997; 72: 362-369.

23. Sauve S, Brousseau P, Pellerin J, Morin Y, Senecal L, Goudreau P, Fournier M. Phagocytic activity of marine and freshwater bivalves: in vitro exposure of hemocytes to metals (Ag, Cd, Hg and Zn). Aquat Toxicol 2002; 58: 189-200.

24. Shapiro HM. Practical flow cytometry, $2^{\text {nd }}$ Wiley-Liss, New York, 1988.

25. Sheehan D. Applications of invertebrate cell culture in studies of biomarkers and ecotoxicology. In: Mothersill C, Austin, eds. Aquatic invertebrate cell culture. Chichester: Springer Praxis-Publishers, 2000: 337-359.

26.Simms HH, D'Amico R, Burchard KW. Intraabdominal sepsis: effects on polymorphonuclear leukocyte Fc receptor-mediated phagocytosis. J Surg Res 1990; 49(1): 4954.

27. Torreilles J, Guerin MC, Roch P. Peroxidase-release associated with phagocytosis in Mytilus galloprovincialis haemocytes. Develop Comp Immuno 1997; 21(3): 267-275.

28. Wilson JT, Pascoe PL., Parry JM, Dixon DR. Evaluation of the comet assay as a method for the detection of DNA damage in the cells of a marine invertebrate, Mytilus edulis L. (Mollusca: Pelecypoda). Mut Res Fund Mol Mec Muta 1998; 399: 87-95. 